\title{
ZFYVE19 wt Allele
}

National Cancer Institute

\section{Source}

National Cancer Institute. ZFYVE19 wt Allele. NCI Thesaurus. Code C97224.

Human ZFYVE19 wild-type allele is located in the vicinity of $15 q 15.1$ and is approximately 8 $\mathrm{kb}$ in length. This allele, which encodes zinc finger FYVE domain-containing protein 19,

may play a role in the response to DNA damage. A cytogenetic abnormality involving this gene and the MLL gene, translocation $t(11 ; 15)(q 23 ; q 14)$, is associated with acute myeloblastic leukemia. 